Taras Shevchenko National University of Kyiv https://orcid.org/0000-0003-3873-2525

\title{
Yuliia NESTERIAK
}

Taras Shevchenko National University of Kyiv https://orcid.org/0000-0002-5955-7693

\section{Maryna GRYNCHUK}

Taras Shevchenko National University of Kyiv https://orcid.org/0000-0001-5835-2808

\section{UKRAINIAN HISTORICAL ISSUES IN POLISH MEDIA IN THE CONTEXT OF A HYBRID WAR: BETWEEN MYTHS AND POST-TRUTH}

The basis of current relations between Ukraine and Poland, the image of Ukraine and Ukrainians in the information and public domains of both countries are to a large extent determined within the historical aspect. This article will focus on how this issue has penetrated Poland's information and media spheres, where it has become a tool in both internal and external rhetoric by political parties and social movements in a destructive or manipulative way. It becomes a significant part of the content and purpose of their political operations and a key tool for propaganda and agitation targeting their supporters. The general theoretical framework of the study proposed are memory studies as a multidisciplinary field which combines intellectual strands from anthropology, education, literature, history, philosophy, psychology, and sociology, among others (Roediger, Wertsch, 2008). The historical politics is the most commonly used definition within memory studies. The concept is used synonymously with the term "politics of memory" in Polish scientific works. It is used in both scientific and journalistic discourse and is of interest to sociologists, culturologists, anthropologists, political scientists, and communication experts. Therefore, the interpretation of this concept is a challenge for modern science. Despite the fact that concepts are synonymous, Katarzyna Kącka emphasizes that the politics of memory is not about establishing historical truth, it's about exploiting for certain purposes a specific image of the past, as it stands in the collective and individual consciousness. It is also the ability to shape the community's perception of the past to facilitate the impact on the present (Kącka, 2015).

Researchers say the term "historical politics" was first used in the postwar Germany (Kutiawin, 2008; Michałek, 2011). The concept of historical politics was officially put up for public discussion after 1989. It emerged in the Polish research circles in the context of the international relations studies.

Emphasizing the importance of historical politics in modern public life, Anna Wójcik notes that the government has a chance to form the expected vision of the state 
and people in the international arena by using the tools of historical politics (Wójcik, 2016). D. Gawin also combines historical politics with international relations, claiming that in the internal sphere, it is a vision of the place of historical memory in politics, and in a broader sense - in public life (Wyborcza, 2005). Summarizing the existing definitions of historical politics, Anna Wójcik claims that historical politics is a category of history that serves the historical awareness of society, especially the perception of territorial affiliation and strengthening the discourse of the past in order to develop permanent national ties regardless of modifications and current public policies. She states that in political science, it can be interpreted as a "product" that nations and states are trying to "sell" in international markets to satisfy their political and economic ambitions. Tomasz Leszkowicz defines historical politics as a set of activities carried out by political formations (primarily state-owned), related to promoting a certain vision of history. He also emphasizes that historical politics has two dimensions: external, aimed at the international environment; and internal, aimed at forming the way of thinking about the past among the country's citizens. Historical politics is a natural attribute of public policy (Leszkowicz, 2015). Katarzyna Kącka emphasizes the role of mass media in the process of formation and dissemination of historical politics (Kącka, 2015). Sociologist Lech M. Nijakowski, using the concept "politics of memory," emphasized that it includes all actions - conscious and unconscious, intentional and unintentional - that lead to the consolidation and strengthening of the collective memory of Poles or to its altering (Nijakowski, 2008). Although media discourse around memory studies aims primarily at the attainment of internal goals, it also defines the agenda of interstate relations, due to its cross-border nature. It should be noted that this process would not be as acute if the Russian propaganda machine, which sees sowing information chaos that leads to tensions in the Ukrainian-Polish relations as one of its desired results, didn't try to influence it from outside (Pogorzelski, 2017; Gov.pl, 2020; CyberDefence 24, 2020; Mierzynska, 2020).

Chaoticization of communication discourse on the delicate issue of interstate relations may be achieved in many ways, among which we distinguish the most popular one today - cultivation of myths (Barthes, 1957), both established and new, as well as the use of manipulative opportunities of post-truth, including dominance of interpretations, often pseudoscientific, over historical facts, which are recognized by professional circles of historians and are not subject of fundamental discussions (Cambridge Dictionary, 2020). Besides, there is an uncontrolled spread of populism as a leading political format (De Witte, 2020), which defines the style and substitutes the content of their interaction with citizens through the media. They are rating-oriented and therefore they actively channel certain information to specific audiences. This threat is pointed out by Ukrainian researcher Hryhoriy Perepelytsya, who states that "the transformation of political elites is ongoing place in Europe and the West in general. Radicals and populists tend to replace value-oriented leaders" (Day, 2019). The fact that Ukrainian-Polish issue was brought to top agenda in literary, mainly historical and journalistic, discourse, is the evidence of that trend. For example, during the first week of November, 2018, alone, two book presentations were held in Kyiv by Polish and Ukrainian authors. One book was "Nostalgia and Politics" by a Polish public figure, publicist, and expert in Polish-German relations, author of studies about the politics 
and European conflicts' memory, Kazimezh Vuychitsky, and another one was "Shcherbets Sword and the Ukrainian Gate: Ukrainian-Polish relations from the sections of the Polish-Lithuanian Commonwealth until today" by Ukrainian historian Svyatoslav Lipovetsky.

The purpose of the article is to summarize the state of discourse in Polish media (mainly online publications) concerning issues of Ukrainian-Polish relations in the context of approaches to historical policy, given the fact that media in both Ukraine and Poland are subject to Russian information influence. This factor significantly determines the tones and bias of media discourse regarding historical policy, which is formed mainly based on politicized myths exploited by populist politicians of different ideological affiliations, and which has acquired typical features of post-truth. It should also be noted that the process is taking place in the context of destructive information influence of a third party, whose interest is to maintain controlled tensions in Ukrainian-Polish relations, in particular through the media sphere and mediatization of political life. Based on scientific analysis, we seek to prove the need for political leadership to make utmost efforts to return the discussion of historical politics to the academic domain, which will allow reducing tensions in media discourse and introducing narratives developed by research centers and government agencies, focused on national interests of both countries, rather than designed by third parties. We consider it the applied task of our research. It should be noted that the article is interdisciplinary, based on the intersection of political science and media research. It has no aim to contribute to historical science, namely to reviewing the World War 2 period. Authors share the view that the relationship between media and memory is comprehensive, as the media are one of the main sources of information about the past and a channel for spreading the knowledge about the past, as well as a place for public expectation of memory as the first draft of history. As well, it turns out that people's attitude towards events influences the way they present information about past, present, and future. While communicating with the target audience, media usually use inclusive language and perceive the audience as a part of a social group with certain values and needs (Kitch, 2008).

Research of publications of the two online editions - KrytykaPolityczna.pl and wPolityce.pl - became the empirical basis of the study. The systematic, algorithmic sample of news covered preconceived views (myths) existing in Polish society and were further interpreted in media in the format of post-truth. In the past and today, citizens of both countries have distorted cultural maps in the context of common history. Accordingly, the task is to review them, to find a real way, rather then follow someone else's geopolitical interests.

The choice of media sources is justified by the fact that these publications were included neither in the mainstream Polish media like "Gazeta Wyborcza," "Rzeczpospolita" or "Nasz Dziennik" (they have a prudent editorial policy, and their readers are consumers of intellectual media and critical thinkers), nor to marginal editions, such as kresy.pl. It is quite reasonable that researchers also avoided studying the resources of the far right field: https://dziennik-polityczny.com/ or leftist ones: http://tygodniknie. $\mathrm{pl} /$, as well as openly propagandistic https://pl.sputniknews.com/ and other affiliated resources (RT, RIA Novosti). Instead, KrytykaPolityczna.pl and wPolityce.pl clearly represent the main political vectors available in the country. The first is liberal and the 
latter - conservative. Accordingly, messages are rather clear and in accordance with the direction of their affiliation. Also, the experience of Ukraine shows us that destructive information influences reach their targets precisely through the media ranking below the top knotch ones, to which the political establishment and government agencies pay special attention. It's done through those mediocre, lower-profile online editions, with unstable and emotionally vulnerable audiences that are easy to manipulate (White Book of the Special Information Operations Against Ukraine 2014-2018, 2019). Thematic reports of Polish think tanks referenced below have also been studied.

It is important to note that not all publications in Ukrainian media of the country's western regions are controversial regarding issues of Ukrainian-Polish relations. For example, let's consider an article "Who is Jacek Kuron, in Honor of Whom Lviv Named Its Square", penned by Zakhar Protsyuk and published in the online edition "Tvoye Misto" ("Your City") (Protsyuk, 2019). The young Ukrainian author writes about a Lviv-born Polish dissident, an activist with the anti-communist opposition. Jacek Kuron is important for Ukraine primarily because of his position regarding PolishUkrainian mutual understanding. His efforts to improve relations between the two nations, as well as his often-unpopular public position regarding the events of historical past, significantly influenced the development of Polish-Ukrainian relations. Accordingly, it is possible to state that nowadays we can observe comprehension of impermissibility of further emotional escalation in the public debate about historical policy issues, which is ongoing in media discourse of the two countries (Zashkilnyak, n.d.; Kipiani, 2017; Trudnowski, 2019; Dzieje.pl., 2019).

It is possible to monitor how Polish media cover events in Ukraine. According to Alexandra Martinez, the researcher with Maria Curie-Sklodowska University, "emotional tone and expressive linguistic means are widely used in the coverage of events on the Kyiv square." She states that information about Ukraine in the acclaimed print media that are focused on analytical interpretation of events, such as "Gazeta Wyborcza," "Rzeczpospolita," "Nasz Dziennik," and other Polish media, is too expressive. "The appearance of such (emotional) lines in a large print edition ('Gazeta Wyborcza') is more than strange and unacceptable" (Martines, 2015).

Typical internal relations between political parties fighting for electoral influence also affect media coverage of certain events (Kirvel, 2015). In Ukraine, the problem has become more relevant in the information sphere after Volodymyr Vyatrovych was appointed Director of the Ukrainian Institute of National Memory in the spring of 2014. He was the one who focused attention on glorification of OUN-UPA and personified the process of decommunization in Ukraine (Riabenko, Kuzio, 2020). Accordingly, in Poland it happened in November 2015, when the government fully formed by the party "Prawo i Sprawiedliwość" ("Law and Justice") led by Jaroslav Kaczynski came to power. In 2016, the Polish feature film "Volyn" was released, telling a story of the most dramatic period of the Ukrainian-Polish relations, and, naturally, the event most discussed by historians - the Volyn tragedy. The Volyn topic became the subject of research of Polish centers of expertise. The Warsaw Institute has prepared a report "Poland through Eurasian eyes: Russian propaganda messages in the media." Polish experts analized key messages produced by Russia and circulated in Polish media. It has been confirmed that the distinctive feature of Russian efforts in Europe is its ability 
to adapt propaganda (based on institutional misinformation) and its tools to the specific features of a target country. They reach their audiences through a variety of channels. Among them: mass media, international charitable organizations, and initiatives to defend traditional value systems. They are supported by governmental and non-governmental organizations, think tanks, the Orthodox Church, part of the Russian and Russian-speaking communities abroad, as well as far right-wing or extremist groups who consider Vladimir Putin, Russian Eurasianism, and Orthodoxy as salvation for Europe. The perception of Russia in Europe is also determined by "agents of influence," including scholars, journalists, artists, politicians, and businessmen who shape public opinion and attitude towards Russia. There is a similar detailed study available about them in the territory of the "collective West" (Smagliy, 2019).

Third parties significantly influence Polish media's view of the historical issues of Ukrainian-Polish relations. They incorporate these relations into their own vision of the geopolitical future of the region of Central and Eastern Europe. We are talking primarily about the United States and Russia. The Russian institutionalized propaganda machine consistently produces its vision of Poland and the way it should be in the view of those who profess ideological Eurasianism. The integral element of the Eurasian concept is the constant emphasis on the fact that Poland is heavily influenced by the United States, being its "Trojan Horse" in Europe. Therefore, Poland is used to fight Germany in the European Union. With the help of the Visegrad Group it forms an anti-German bloc to create antagonisms between the New and Old Europes. The bloc sabotages all European Union's aspirations to deepen continental integration, taking into account Russia's interests and "legitimate encroachments." Instead, it promotes the Trans-Atlantic concept. Poland's goal is to "gather lands" from the Baltic Sea to the Black Sea, including the territory of Ukraine, and, with the agreement of the United States, to allow deployment of US military bases. This will allow the US to dictate its policy to the EU. Eurasians consider it to be unacceptable (Kwiecień, 2017).

Researchers with the Warsaw Institute summarize propaganda messages in the "Ukraine-Poland" dichotomy aimed at influencing Polish and foreign audiences. It is here that propagandists often turn to historical and economic problems, as well as the contradictory and emotionally colored current political situation. It is a two-sided narrative aimed at antagonizing Poles and Ukrainians.

On the one hand, it tars Ukrainians and uses them in boogeyman stories designed for the Polish audiences:

- Ukraine does not recognize the massacres of Poles in Volyn during the World War 2, uses Bandera symbols, and doesn't intend to honor the memory of victims;

- Ukrainians take jobs from the Poles, fail to integrate into society, and take local lifestyle for granted, while their number leads to closed communities being formed;

- what happened in Volyn may happen again in the future.

On the other hand, Poles are presented as those who despise Ukraine and wish to take advantage of its status as a fallen state that seeks identity.

- Poland considers Ukrainians to be people of lower level, and exploits them as cheap work force;

- Ukraine is a pawn in the Polish concept of "Intermarium," which has a goal to create Great Poland (Polska od morza to morza). The aim of Poland is to restore the 
assets in Western Ukraine, which Poland will demand back from the moment of the expected dissolution of Ukraine;

- Poland will use its national minority to increase influence in Ukraine using the "Polish Card," which confirms loyalty to the "Polish nation." Poland is also willing to give up its minority (it doesn't care about persecuted Poles) for the sake of protecting American interests in this part of Europe (Kwiecień, 2017).

In our opinion, the purpose of misinformation is to divide the Polish society. Following the example of how Russia does the same with the Ukrainian society (Ministry of Temporarily Occupied Territories, 2018). Therefore, it can be considered as a threat to the national security of the country, its political, social, and territorial unity (Unian, 2018). After all, every European country, even a stable democracy, has political movements, albeit marginalized, that follow regional individualism or proto-separatist ideas (Verhofstadt, 2020). In fact, this is in line with Russia's general doctrinal disinformation policy strategy when "pro-Kremlin media will continue opportunistically exploiting conspiracy theories and other disinformation narratives around COVID-19, undermining the EU, attacking the US or 'Western elites', or fomenting public fear and distrust" (EUvSDISINFO, 2020).

Polish researchers, including Michał Urban of the Jagiellonian University, emphasize that Russia's propaganda operations focus on reviving ethnic and historical conflicts in Central and Eastern Europe in order to paralyze the construction of an anti-Russian axis and to gain sympathy for their actions. The role played by Russia and its supporters of the Polish-Ukrainian memory conflict that's focused on the Volyn massacre is a prime example of the "divide and rule" tool.

According to Michał Urban, Russian propaganda portrays Ukrainians as anti-Polish, brutal nationalists. Meanwhile, facts and memory, as well as varying historical and identity discourses are subject to manipulation (Urban, 2016). This vision is based on one of the European Union's documents, which has been defining the EU policy towards Russia since 2014. Titled "The EU's Russia policy: Five guiding principles," the document states that relations between EU and Russia have been complicated, especially starting 2014, when Russia illegally seized Crimea. It is also noted that the "EU's Eastern Neighbourhood remains a zone of confrontation; EU security is threatened by dependence on Russian energy imports and the destabilising effects of aggressive propaganda" (European Parliament Think Tank, 2018). Some effective steps have been taken on by the Kremlin, while implementing an information policy that other countries call disinformation. The North Atlantic Alliance and EU membership, which are of great strategic importance for Poland, may be the subject of attack throught attempts to organize a social movement of dissatisfied people. For example, the Yellow Vests movement in France, which every weekend at the end of 2018 and the beginning of 2019 would made the center of Paris a venue for radicalized protests. The sowing of chaos, the game of emotion, and the feeling of injustice leads to the general undermining of public trust in their leaders and the undermining of the legitimacy of the governing national and supra-national bodies (Kwiecień, 2017).

Wojciech Konończuk, the analyst with the Kennan Institute, believes the idea of Polish-Ukrainian relations undergoing a crisis is just too simplistic. The problem is that countries have different perceptions of their tragic past amid mutual politicization 
of history, supported by senior politicians and picked up by media. Poland's support for Ukraine in strategically important issues is indisputable, while for the most part remaining unnoticed by the general public on both sides of the border. In the face of a plethora of internal problems, historical contradictions often become the instrument for shifting voters' focus away from the domestic agenda during election campaigns or other politically sensitive periods. The problem is partly explained by the fact that the trust was undermined by a risky attempt to pursue a historical memory policy in internal debate. This took place amid the loss of systematic communication and interaction by parties (governments, state institutions, and scholars). The analysis of media reports and various expert opinions concerning the current state of relations between Poland and Ukraine a conclusion can be drawn that historical issues take precedence over pretty much anything else. Polish media mention Ukraine within geopolitically significant developments, in historical, and migration narratives, states Dariusz Baran (Baran, 2016). According to the traditional and online media of both countries, relations between Warsaw and Kyiv have deteriorated due to controversies over the interpretation of historical events. Throughout 2018, there were five peak bursts of Ukraine coverage in media, among which were a series of reports on the amendments to the law on the Institute of National Remembrance (IPN) In Poland. One of the complicated episodes that turned out to be a key point in Polish-Ukrainian relations is the massacre of Poles in Volyn and Eastern Galicia, carried out by the Ukrainian Insurgent Army (UPA) during 1943-1944, which resulted in 100,000 civilian casualties on the Polish side. This ethnic cleansing is widely recognized as genocide by Polish and Western historians, according to Wojciech Konończuk (Journal du Cameroun, 2018). According to the content analysis conducted within this study the Polish news agency PAP throughout 2018 had historical topics as the leading ones in their Ukraine reports bearing negative connotations. Besides the Volyn massacre issue, the agency covered historical politics in general, the activity of OUN-UPA, and leaders of the Ukrainian insurgent movement - Stepan Bandera and Roman Shukhevych. An interesting point: pieces about Ukrainian labor migrants mentioned their positive attitude towards Stepan Bandera. That year, PAP published a total of 270 reports directly or indirectly related to Ukraine. Among them, $39(14 \%)$ had a negative or partially negative connotation. Among these pieces, $16(41 \%)$ were focused on historical politics of both countries, activity of the OUN-UPA and the SS Division Galicia, as well as glorification of Stepan Bandera and Roman Shukhevych. The problem is also under the review by Ukrainian expert circles. For example, there is a study "The role of Polish media in socio-political processes and foreign policy of the state," conducted by Marta Hnatyshyn, where she used content analysis tools on a large array of publications from two online editions - KrytykaPolityczna.pl and wPolityce.pl. Overall, 244 materials on portal Wpolityce.pl and 109 materials on portal KrytykaPolityczna.pl have been analysed, published from October 25, 2015, to April 25, 2018.

It is important to note that the main difference in presenting information in these media is their understanding of historical issues. It is about using the phrase "historical truth" as part of media style in assessing events in the historical political discourse. KrytykaPolityczna.pl approaches the issue of the Volyn tragedy, the figures of Stepan Bandera and Roman Shukhevych, as well as the "historical truth," more from 
the compromise-driven scientific perspective. On the wPolityce.pl portal, historical topics are linked to politics (wPolityce, 2016). In particular, this is achieved through rather traditional linguistic means. For example, the wPolityce.pl portal presents the issue of "historical truth" regarding ethnic cleansing in Volyn by using the following expressions: "Volyn massacre" (wPolityce, 2018), "genocide of the neighboring nation" (Żyszkiewicz, 2016), "OUN-UPA crime" (wPolityce, 2017). Based on the articles analyzed, the researcher makes a conclusion that, despite the emotional sharpness of publications, both nations are presented as equal both in historical retrospect and at the present time. On the one hand, historical topics are the cause of political conflicts between the two states, while on the other - they have little effect on nations' mutual perception and attitudes. So, it is possible to make an assumption that the "realities" designed by media differ from the real world.

It is a well-known fact that one of the features of modern media is their ability to influence the perception of reality, and sometimes even to form an alternative media reality. So, in matters of historical politics, media create a simulation of modern-day socio-political reality. As a tool of realization of ideological and political goals, which also serve as constructs of ruling elites or the opposition, media change the essence of social phenomena and processes, which makes it impossible to determine which reality is true and thereby modifies the collective memory. Simulations become "real," they misinterpret the meaning of modern and historical events, depriving people of the opportunity to comprehend truth. Andrzej Szpocinski emphasizes the emotional nature of collective memory, which changes along with the changing value system in the given group, including under the influence of media (Szpocinski, n.d.). As the result of content analysis of online publications, it was found that, unlike previous historical and ethnic contexts, human-level relations are devoid of direct political implications. In most cases, reports were related to social topics, search, working conditions and wages. Representation of human-level contacts between Ukrainians and Poles on online resources analyzed depends on the information discourse prevailing in the country, and most importantly, on media outlets' political affiliation.

The fact of the OUN-UPA's heroization became an argument for wPolityce.pl portal to cite politicians and portray the strengthening of radical sentiments among Ukrainians. It was revealed that the most popular stereotypes are about Volyn, referring to OUN-UPA as Nazis, and superimposing their image onto modern Ukrainians. Maybe, it is due to the fact that this media outlet supports a more conservative centerright position. The sensitive topic of the Volyn tragedy demands a careful attitude to its various aspects by both sides. As researchers, we share Łeonid Zaszkilniak's opinion that "a historian, like a doctor, should be aware of the impact of his judgments on many people and communities. At this point, it is worth remembering the medical principle - 'do no harm"' (Zaszkilniak, n.d.). On the KrytykaPolityczna.pl, Ukraine is presented as the country with a range of internal problems (corruption, reform process, and war with Russia in the Donbas region), where people suffer from continued abuse by authorities, while being more opposed to their own government than to the Poles (Saturczak, 2016). It was also stated that radical sentiments among Ukrainians are not any more prevailing than in the rest of Europe. It should also be noted that historical politics of the Polish government, "the importance of which, in addition, was partly 
strengthened by media" (right-wing), was discussed in these media (Sutowski, 2016). Therefore, media create tensions. In most cases, it depends on their ideological orientation. While the conservative wPolityce.pl portrayed Polish-Ukrainian relations in a more emotional and sensationalized way, the leftist KrytykaPolityczna.pl mitigated controversies by offering opposing views and opting to look at the core of ther existing issues, taking into account multiple perspectives. Representation of the two nations as equal both in the past amn present indicates that the historical topic affects people's mutual perception, sparking political rows between the two states. It highlights a greater connection between political and media systems and also emphasizes the trend to distance media away from social issues. The media have become more of a tool for politicians. Serhiy Datsiuk points to a similar process - politicization of memory studies, which is manifested, in particular, in the minimal influence of research and scientific position on the formation of historical memory politics (Datsiuk, 2018). We must state that regardless of political affiliation - be it conservative or liberal - all Polish media have Ukraine-Poland relations as part of their agenda, making them a marker for various political forces. In this way, a sustainable rhetoric is being formed with an emphasis on historical stereotypes, replicated in Polish media and socio-political discourse, eventually making its way to Poland's foreign policy. According to Jerzy Kordas, the Polish-Ukrainian dispute over history has a catastrophic impact on today's relations between the two countries, affecting the Ukrainian minority and Ukrainians living in Poland, toward whom aggressive attitudes are on the rise. Both countries ultimately lose in the dispute, while Russia benefits (Kordas, 2017).

To summarize, it is necessary to highlight interdependence between the changes in Poland's state policies and their media's efforts to broadcasting, highlighting, and forming stereotypes. The current official course of Polish authorities, based on conservative political views, has put on top agenda historical, ethnic, and ideological issues of Ukrainian-Polish relations, while historical stereotypes prevail in media. These media, in turn, have stereotypes overlaid on interstate and human-level relations. It is important to understand the complexity of interdependence in media domain and socio-political processes. Right-wing (conservative) media (wPolityce.pl) portray relations between Poland and Ukraine from the perspective of ro-government political actors. Left-wing (liberal) media, like KrytykaPolityczna.pl, cover the topic by debunking historical stereotypes, anti-Polish sentiments in Ukraine and among Ukrainians. At the same time, both types of media emphasize the significance of historical issues and ensure constant attention to them, making such issues a certain marker for politicians. President Andrzej Duda of Poland became the first foreign leader to congratulate Volodymyr Zelensky on his victory in Ukraine's presidential election in April 2019. The key point of his greetings was hope for a quick "settlement of historical disputes" (Eurointegration, 2019). The two presidents also discussed the topic within their negotiations in commemoration of the 80th anniversary of the outbreak of World War 2. Leaders of European countries and the United States attended the event, while Russian President Russia Vladimir Putin had not been invited to Warsaw (Radio Svoboda, 2019). The desire to continue the dialogue and deepen mutual knowledge of traditions and history was also declared by the Polish Episcopate and the Ukrainian Greek Catholic Church in the document "In Love and Truth," signed by heads of the 
Polish Episcopal Conference and the Ukrainian Greek Catholic Church following the session of the Council of Diocesan Bishops in Jasna Gora (PolUkr, 2019). Problems related to differences in interpretation of historical facts, especially the World War 2 events, remain on the agenda of the Ukraine-Poland bilateral relations, as far as state affairs are concerned. They also affect human-level relations as many Ukrainians and Poles interact in their everyday lives.

During the Ukrainian-Polish conference at the Institute of International Relations that's part of Taras Shevchenko National University of Kyiv in April 2018, Ukrainian historian, Professor Mykola Doroshko noted that nowadays, the Katyn events are gradually being replaced by the Volyn narrative with completely different accents, where Ukrainians or Ukrainian nationalists are presented as criminals. While talking about the intertwining of national security and identity (including historical policy issues), the Ukrainian researcher also stated that Ukrainian politicians should follow the Polish experience and initiate the development of the Eastern policy on Russia, based on Ukraine's national interest and patriotism (Mashkevych, 2015).

Gabriele Woidelko, the author of the article The Polish-Ukrainian Battle for the Past, notes that media of both countries often consider the problem of history as the "clash between Polish and Ukrainian truths." However, the expert claims that it is an oversimplification. In fact, there is no Polish or Ukrainian side in the assessment of the World War 2 events involving Poles and Ukrainians. The picture that is often drawn by Ukrainian journalists and experts is far from being unbiased. They often repeat a "manipulated version of history on demand of the Ukrainian Institute of National Memory." Paradoxically, before the Revolution of Dignity in Ukraine in 2013-2014, there was more pluralism in the country's domestic debate about what has really happened in Polish-Ukrainian relations. For example, in 2013 Jaroslav Hrytsak, one of Ukraine's acclaimed historians, referred to the Volyn massacre as "genocide against the Poles."

One of the goals of Poland's foreign policy is supporting Ukraine in the international arena, promoting its democratization and reforms, as well as the country's European integration path. In general, Ukraine remains a key point in Poland's eastern policy. The social dimension of bilateral relations is rather significant, too. According to the 2017 Kantar public opinion poll, 87\% of Poles consider Ukraine a European country - that's the highest rate among the EU member states. Only 54\% of Germans, $48 \%$ of French and $43 \%$ of Dutch responders agreed with the statement. Moreover, Poles have the best attitude towards towards Ukrainians among all foreign nations (Woidelko, 2017). Over the same reporting period, $81 \%$ of 48,600 Polish respondents spoke out against Russia within Pew Research (Marczak, 2015).

Partnership between Kyiv and Warsaw has strengthened significantly after the 2004 Orange Revolution, where Polish officials Aleksander Kwasniewski and Lech Walesa acted as mediators between the opposing parties. Incidentally, those parties supported diametrically opposing vectors - the collective West and Russia. However, not all issues have been agreed. Some of the negative trends are related to the Kremlin's mass propaganda and political manipulation campaigns, aimed at creating a rift both in their target countries' internal politics and their foreign relations.

We share Andreas Umland's point of view that Ukraine still remains under the influence of Russia, the country posing a threat. In the worst-case scenario, the collapse 
of Ukrainian national economy and public governance as a result of the ongoing Russian hybrid war or further military incursions in Ukraine would destabilize the whole Eastern European region and have catastrophic consequences reaching far beyond Ukraine. Implications of such apocalyptic, yet rather possible, developments would affect basic national interests of Ukraine's closest neighbors, notably Poland. The revival of interwar Polish concept Międzymorze, or Intermarium, is the most promising project which Warsaw could use to help prevent such a scenario from coming to life. Its aim was to form a coalition of states of the Baltic, Black, and Adriatic seas' regions to protect these former colonies of European empires from Russia (and Germany) (Umland, 2018).

Implementation of the idea of "Baltic-Black Sea Union," proclaimed by Prince Adam Jerzy Czartoryski, could strategically define Polish-Ukrainian relations that are now being burdened by differing approaches to historical events in Volyn, the role of the UPA, Polish Government policies in 1930-1939, and pacification of Galicia. Andrzej Duda's “Three Seas Initiative," presented in Ukraine at the annual ambassadors' meeting on August 24, 2016, on the occasion of the 25th anniversary of Ukraine Independence, and later at the summit in Croatia's Dubrovnik, showed that Ukraine still remained beyond the initiative's boundaries, though it could become Poland's ally in this regional union, working together towards building up people's community in the region (Vereshchuk, 2016). As we see, the problem of historical policy, electrified by efforts of both countries' media, affects the promotion of important and pragmatic subregional union of the countries of Central, Southeastern Europe, and the Baltic States. And this is developing against the background of a wider context - a threatening revival of Russia-Germany ties (Nord Stream 2). Creating the Union of the three seas (perhaps, four in the future), is a very timely issue. We can say that the historical policy issue, exploited by populist politicians or radicals groups who introduce them into the media domain where there is a "point of entry" for a third party interested in preserving gray zones in Ukrainian-Polish relations, impedes the successful development of economic, investment, and infrastructure projects. Some of them were initiated by the Polish side, such as the Via Carpathia highway, the "North-South" gas corridor, or a high-speed railway which would link Tallinn and Dubrovnik, with branches to Vienna, Kyiv, Bucharest, Sofia, and Belgrade.

\section{CONCLUSION}

In matters related to the discourse around historical politics in Ukrainian-Polish relations, the official component, presented by presidents or high-ranking government officials, is not a main factor that could definitively determine the rational course of discussion, where participants apply academic conclusions and balanced political statements only. In public domain, statements and agreements of the state leaders of Ukraine and Poland get leveled or even delegitimized by certain media efforts - both internal and external. Moreover, pursuing the latter goal, tools of misinformation and post-truth are used (From-ua, 2019). These instruments are becoming more and more important as the Kremlin is waging its hybrid war targeting the West in order to sow 
chaos and imbalance in social and political life, as well as to specifically influence average citizens through micro-targeting. We have to admit that the activities of Russian information units, including their "elite" media as RT, Sputnik, and RIA Novosti, appear to be rather effective.

Therefore, the media discourse around memory studies is among areas determining the agenda of Ukrainian-Polish bilateral relations. Polish media of various ideological backgrounds are part of the discourse within the framework of historical politics concerning events common for Ukraine and Poland. The tone and emotional coloring of their coverage vary, depending on political affiliations. However, what they have in common is the lack of reference to an academically balanced position, their use of myths deeply rooted over the decades of Soviet rule, and their interpretation of events - of both past and present - in the post-truth format.

Polish media coverage of Ukraine events is sometimes excessively expressive in its nature due to the fact that such reports touch upon topics that are sensitive for the Poles: historical policy, labor migration of Ukrainian nationals, and more. Historical topics, often sparking escalation of political debate between the related institutions of both states, have little effect on the actual inter-nation and human-level perceptions and mutual attitudes. In matters of historical politics, media offer a modern socio-political reality of a simulated nature, altering the essence of social phenomena and processes, thereby modifying the collective memory through the impact on the system of values. Historical politics as part of media discourse is one of the determining factors affecting interstate relations between Ukraine and Poland, as methods of presentation and public interpretation of historical politics affect the image of any state in the international arena. Also, historical topics in media reports are extremely sensitive to external influences and manipulation. Destructive information influences are mostly spun through online publications with mediocre ratings targeting unstable and emotionally vulnerable audiences that are easy to manipulate - rather than not through top-tier media that are in the focus of political elite and government agencies.

The easing of tensions in media discourse could be facilitated by pursuing historical issues based on academic research and narratives focused on national interests of both parties and developed through the joint efforts of research centers and government agencies of Ukraine and Poland.

\section{REFERENCES}

Baran D. (2016), Wizerunek Ukraińców na tamach wybranej polskiej prasy, „Państwo i Społeczeństwo", No. 1.

Barthes R. (1957), Mythologies.

Cambridge Dictionary (2020), Meaning Of Post-Truth In English, https://dictionary.cambridge.org/ dictionary/english/post-truth (26.07.2020).

CyberDefence 24 (2020), Polska celem szeroko zakrojonej kampanii informacyjnej, https://www. cyberdefence24.pl/polska-celem-szeroko-zakrojonej-kampanii-informacyjnej (26.07.2020).

Datsiuk S. (2018), Kolektyvni pretenziyi na mynule, „Ukrayins'ka Pravda”, https://blogs.pravda.com. ua/authors/datsuk/5bab48facb45f/ (31.07.2020). 
Day (2019), Bezpekovi vyklyky dlya zovnishn'oyi polityky, https:/day.kyiv.ua/uk/article/den-planety/ bezpekovi-vyklyky-dlya-zovnishnoyi-polityky?fbclid=IwAR2CM5rNqIaiVqdB9J16yjIz3U G9FW2SELZ8c-49_AFKiiwddEN5qG_B3Bw (19.09.2019).

De Witte M. (2020), Populism Is A Political Problem That Is Putting Democracy At Risk, Stanford Scholars Say, Stanford, https://news.stanford.edu/2020/03/11/populism-jeopardizes-democracies-around-world/ (26.07.2020).

Dzieje.pl. (2019), Dr Ł. Adamski o dialogu z Ukraina: Polska nie może przymykać oczu na kult ludobójców, https://dzieje.pl/aktualnosci/dr-l-adamski-o-dialogu-z-ukraina-polska-nie-mozeprzymykac-oczu-na-kult-ludobojcow (27.07.2020).

Eurointegration.com.ua (2019), Duda poprosyt' Zelens'koho skasuvaty moratoriy na eks.humatsiyi polyakiv, https://www.eurointegration.com.ua/news/2019/06/4/7096910/(19.09.2019).

European Parliament Think Tank (2018), The EU's Russia Policy: Five Guiding Principles, https:// www.europarl.europa.eu/thinktank/en/document.html?reference=EPRS_BRI(2018)614698\&fbclid=IwAR31cLFHRHBsjEBX3Z6ypMhESNJCMPaxaMZps4iK3ixQcM7RvMsS WIFraGo (28.07.2020).

EUvsDISINFO (2020), Back to basics: Ukraine, revisionism, and Russophobia, https://euvsdisinfo. eu/back-to-basics-ukraine-revisionism-and-russophobia/ (27.07.2020).

From-ua (2019), Danylenko C.: "Vidnosyny Iz Rosiyeyu Vyznachayut' Nashe Maybutnye», https:// from-ua.com/intervyu/509529-danilenko-vidnosini-iz-rosieyu-viznachayut-nashe-maibutne. html (28.07.2020).

Gov.pl (2020), Polska na celowniku dezinformacji, https://www.gov.pl/web/sluzby-specjalne/polskana-celowniku-dezinformacji (26.07.2020).

Journal du Cameroun (2018), Poland, Ukraine still divided by WWII massacres, https://www.journalducameroun.com/en/poland-ukraine-still-divided-by-wwii-massacres/ (19.09.2019).

Kącka K. (2015), Polityka historyczna: kreatorzy, narzędzia, mechanizmy działania-przykład Polski, Wydawnictwo Naukowe UMK, Toruń.

Kipiani V. (2017), Viyna dvokh pravd: polyaky pa ukrayintsi u kryvavomu XX stolitti, Vivat.

Kirvel E. (2015), Parlamentskiye partii Pol'shi o konflikte v Ukraine, „Vostok Yevropy. Gumanitarno-obshchestvennyye issledovaniya", No. 1 (1).

Kitch C. (2008), Placing journalism inside memory and memory studies, "Memory Studies", No. 1(3).

Kordas J. (2017), Polska - Ukraina: polityka historyczna w latach 2015-2017, „Politechnika Wrocławska: Studia de Securitate et Educatione Civili”, No. 7.

Kutiawin W. (2008), Pamięć historyczna Rosjan. Między dziejopisarstwem akademickim a historiografia , ludowa”, in: Pamięć i polityka historyczna. Doświadczenia Polski i jej sąsiadów, (ed.) S. M. Nowinowski, J. Pomorski, R. Stobiecki, Łódź.

Kwiecień J. (2017), Poland through Eurasian Eyes: Russian Propaganda Messages in the Media, Warsaw Institute, https://warsawinstitute.org/poland-eurasian-eyes-russian-propagandamessages-media/ (19.09.2019).

Leszkowicz T. (2015), Czym jest polityka historyczna i do czego sluży?, https://histmag.org/Czym-jest-polityka-historyczna-i-do-czego-sluzy-11411 (25.07.2020).

Marczak M. (2015), Newsweek Świat Globalny Sondaż: Polacy największymi rusofobami świata, https://www.newsweek.pl/swiat/polacy-najwiekszymi-rusofobami-swiata-czy-polacy-lubiarosje/zlgyynd?fbclid=IwAR0Wh1_T355GJYhhGX6twMir4Gh8YivQrJbFqyREeJEEVhe76hYDrZU1CtE (2.12.2019).

Martines A. (2015), Ukrainskiy krizis v pol'skikh pechatnykh SMI, „Vostok Yevropy. Gumanitarnoobshchestvennyye issledovaniya”, No. 1 (1). 
Mashkevych M. (2015), Skhidna pol's'ka polityka u XX-na pochatku XXI st.: kontseptsiyi ta interpretatsiyi, Nika-Tsentr.

Michałek J. (2011), Współcześnie o przeszłości, czyli wplyw polityki historycznej na kształt podręczników Szkolnych, 16th ed.

Mierzynska A. (2020), Kreml testuje polskie ,, czerwone linie”, politycy nie reaguja. Wojna informacyjna narasta, https://oko.press/kreml-wojna-informacyjna-narasta/ (26.07.2020).

Ministry of Temporarily Occupied Territories (2018), V. Chernysh: Rosiya prahne zruynuvaty diyuchi politychni soyuzy, https://mtot.gov.ua/vadym-chernysh-nato (27.07.2020).

Nijakowski L. (2008), Polska polityka pamięci, Esej socjologiczny, Warszawa.

Pogorzelski P. (2017), Zagrożenie rosyjska dezinformacja w Polsce i formy przeciwdziałania, Kolegium Europy Wschodniej im. Jana Nowaka-Jeziorańskiego we Wrocławiu, Wojnowice, http://www.kew.org.pl/wp-content/uploads/2016/12/Piotr-Pogorzelski-Zagro\%C5\%BCenierosyjsk $\% \mathrm{C} 4 \% 85$-dezinformacj\%C4\%85-w-Polsce-i-formy-przeciwdzia $\% \mathrm{C} 5 \% 82$ ania.pdf (25.07.2020).

PolUkr (2019), UGKC ta Yepyskopat Pol'shchi domovylysya prodovzhuvaty dialoh i pohlyblyuvaty prymyrennya, Pol's'ko-ukrayins'kyy portal, http://www.polukr.net/uk/blog/2019/08/ugkc-tayepiskopat-polshi-domovilisya-prodovzhiti-dialog-i-poglibiti-primirennya/ (19.07.2020).

Protsyuk Z. (2019), Khto takyy Yatsek Kuron', na chest' yakoho L'viv nazvav ploshchu, http://tvoemisto.tv/exclusive/polskyy_dysydent_zi_lvova_istoriya_zhyttya_yatseka_kuronya_95004.htm 1?fbclid=IwAR1e7YY42o2UOP9T9jzIotW7JbqGpowZqjnGaz82nAe-1b5GzpxD_sP5brhg (19.09.2019).

Radio Svoboda (2019), 80-richchya Druhoyi svitovoyi viyny: chomu do Varshavy zaprosyly Zelens'koho, ale ne zaprosyly Putina, https://www.radiosvoboda.org/a/druga-svitova-80-rokiv/ 30140507.html (19.09.2019).

Riabenko S., Kuzio T. (2020), From The Great Patriotic War To The Second World War: Decommunisation Of Ukraine'S Memory Politics, https://neweasterneurope.eu/2020/07/07/fromthe-great-patriotic-war-to-the-second-world-war-decommunisation-of-ukraines-memorypolitics/ (27.07.2020).

Roediger H. L., Wertsch J. V. (2008), Creating a new discipline of memory studies, "Memory Studies", No. 1(1).

Smagliy K. (2019), Hybrid Analytica: Pro-Kremlin Expert Propaganda in Moscow, Europe and the U.S.: A Case Study on Think Tanks and Universities, https://imrussia.org/en/news/2997hybrid-analytica-pro-kremlin-expert-propaganda-in-moscow,-europe-and-the-u-s-a-casestudy-on-think-tanks-and-universities\%20 (19.09.2019).

Szpocinski A. (n.d.), Pamięć zbiorowa a mass media, https://www.nck.pl/upload/archiwum_kw_files/artykuly/4._andrzej_szpocinski_-_pamiec_zbiorowa_a_mass_media.pdf (31.07.2020).

Trudnowski P. (2019), Potrzeba polsko-ukraińskiego zrozumienia, a nie wzniostych deklaracji, https://klubjagiellonski.pl/2019/07/18/potrzeba-polsko-ukrainskiego-zrozumienia-a-niewznioslych-deklaracji/ (27.07.2020).

Umland A. (2018), Why Warsaw is not supporting Kyiv as much as it should, http://neweasterneurope.eu/2018/01/16/warsaw-not-supporting-kyiv-much/ (2.12.2019).

Unian (2018), Polityka Rosiyi stanovyt' zahrozu dlya Pol'shchi - Hlava MZS, https://www.unian.ua/world/10050812-politika-rosiji-stanovit-zagrozu-dlya-polshchi-glava-mzs.html (27.07.2020).

Urban M. (2016), Ukrainiec jako wróg: rosyjska propaganda i jej wplyw na nastroje w Polsce, „Ante Portas - Studia nad Bezpieczeństwem”, No. 1(6). 
Vereshchuk I. (2016), "Trymor"ye», abo Nichoho pro nas bez nas, https:/detector.media/blogs/ article/120182/2016-10-31-trimore-abo-nichogo-pro-us-without-us (2.12.2019).

Verhofstadt G. (2020), Is COVID-19 Killing Democracy?, https://www.project-syndicate.org/ commentary/covid19-democracy-violations-by-guy-verhofstadt?barrier=accesspaylog (27.07.2020).

White Book Of The Special Information Operations Against Ukraine 2014-2018 (2019), https:// drive.google.com/file/d/1DEkozHjkCpbRozR3EWBUKcwnguUfJ0dJ/view?fbclid=IwAR2AsQ 88rT-hOjg3 YaM-zyCmWGaYLtL-Nz1EHCoChV2-qGMP0N_To8kZKLs (26.07.2020).

Woidelko G. (2017), The Polish-Ukrainian Battle for the Past, http://carnegieeurope.eu/strategiceurope/75029 (2.12.2019).

Wójcik A. (2016), Polityka historyczna hako forma budowy wizerunku Polski na arenie międzynarodowej, „Świat Idei i Polityki”, No. 16.

wPolityce (2016), Sonik o Wolyniu: "To byto ludobójstwo. Pytanie, w jakiej mierze to wptynie na politykę ukraińska. Ukraina musi się przyzwyczaić do prawdy”, https://wpolityce.pl/polityka/300405-sonik-o-wolyniu-to-bylo-ludobojstwo-pytanie-w-jakiej-mierze-to-wplynie-napolityke-ukrainska-ukraina-musi-sie-przyzwyczaic-do-prawdy (2.12.2019).

wPolityce (2017), Nasz wywiad. Dr Szarek: IPN nie może wskazywać Ukrainie, jakich ma wybierać bohaterów, ale nie może też milczeć wobec zbrodni UON-UPA, https://wpolityce.pl/polityka/367731-nasz-wywiad-dr-szarek-ipn-nie-moze-wskazywac-ukrainie-jakich-ma-wybieracbohaterow-ale-nie-moze-tez-milczec-wobec-zbrodni-uon-upa (2.12.2019).

wPolityce, (2018), Skandaliczne słowa posła Nowoczesnej. Dlaczego doszło do Rzezi Wołyńskiej? "Wymagaliśmy od Ukrainców pracy ponad miarę", https://wpolityce.pl/polityka/384449-skandaliczne-slowa-posla-nowoczesnej-dlaczego-doszlo-do-rzezi-wolynskiejwymagalismy-od-ukraincow-pracy-ponad-miare (2.12.2019).

Wyborcza.pl (2005), Po co nam polityka historyczna - Debata „Gazety”, https://wyborcza. $\mathrm{pl} / 1,76842,2945729 . \mathrm{html}(25.07 .2020)$.

Zashkilnyak L. (n.d.), Ohlyad oroblem spil'noyi (vazhkoyi) istoriyi Ukrayintsiv i Polyakiv XX stolittya, Ukrainian Institute of National Remembrance, https://old.uinp.gov.ua/news/oglyadproblem-spilnoi-vazhkoi-istorii-ukraintsiv-i-polyakiv-khkh-stolittya (27.07.2020).

Zaszkilniak Ł. (n.d.), Przegląd problemów wspólnej (trudnej) historii Ukraińców i Polaków w XX wieku, Instytut Pamięci Narodowej.

Żyszkiewicz W. (2016), Pokusy geopolityki, prymat aksjologii, https://wpolityce.pl/polityka/303660pokusy-geopolityki-prymat-aksjologii (2.12.2020).

\begin{abstract}
Ukrainian-Polish relations have been rather controversial in terms of historical policy lately, and it has a negative impact on interstate relations. On the one hand, in the foreign policy discourse Poland is considered to be one of the leading advocates of Ukraine in the collective West, along with Lithuania, and on the other hand problems of historical and humanitarian character permanently arise in bilateral relations, which form a negative background, become a subject to manipulation by third countries, and exacerbate relations both at the interpersonal and inter-institutional communication levels. The additional factor that complicates the understanding of historical policy issues is media of both countries, where the old and new myths, elements of post-truth and emotional subjective evaluations of the non-professional level penetrate beyond the historical corporate society. Populist politicians of the left and right ideological flanks try to take advantage
\end{abstract}


of it, but it becomes an obstacle to political understanding, and complicates the investment development of a large subregion of the countries of Central, Southeastern Europe and the Baltic States. Historical policy has become a part of an information security, and some third countries, in our case it's the Russian Federation, use this factor during the implementation of hybrid war tasks against Ukraine and the countries of the European Union. The article assumes that only the change of political rhetoric, the avoidance of populism regarding historical relations of two neighboring nations, the strengthening of corporate responsibility of national media in matters of historical policy's coverage are able to neutralize the influence of radical political trends inside the countries, and outside - the influence of other states which are not interested in overcoming the tragic plume of history in Poland and Ukraine. Authors of the article do not aim to study or compare purely historical positions. This is about media tools and their role in the historical policy discourse.

Keywords: historical policy, media sphere, post-truth, mythologizing, chaotization of information space, national security, hybrid war, populism

\section{UKRAIŃSKIE KWESTIE HISTORYCZNE W POLSKICH MEDIACH W KONTEKŚCIE WOJNY HYBRYDOWEJ: MIĘDZY MITAMI A POSTPRAWDĄ}

\section{STRESZCZENIE}

Stosunki ukraińsko-polskie charakteryzują ostatnio kontrowersje dotyczące polityki historycznej, co odbiło się negatywnie na stosunkach między obydwoma krajami. Z jednej strony w dyskursie o polityce zagranicznej Polska uznawana jest za jednego z czołowych orędowników Ukrainy na Zachodzie - obok Litwy, z drugiej zaś w stosunkach dwustronnych stale pojawiają się problemy o charakterze historyczno-humanitarnym tworzące negatywną atmosferę i podlegające manipulacji ze strony państw trzecich, zaostrzając stosunki zarówno na poziomie komunikacji międzyludzkiej, jak i międzyinstytucjonalnej. Dodatkowym czynnikiem utrudniającym zrozumienie kwestii polityki historycznej są media w obu krajach, gdzie stare i nowe mity, elementy postprawdy oraz emocjonalne, subiektywne oceny dokonywane przez nieprofesjonalistów mają większy wpływ niż podejście historyków. Próbują to wykorzystać populistyczni politycy z lewicowej i prawicowej flanki ideologicznej, ale kwestie te stają się także przeszkodą w porozumieniu politycznym i komplikują inwestycje i rozwój dużego subregionu krajów Europy Środkowej i Południowo-Wschodniej oraz krajów bałtyckich. Polityka historyczna stała się częścią bezpieczeństwa informacyjnego, a niektóre państwa trzecie, w tym przypadku Federacja Rosyjska, wykorzystały ten czynnik w trakcie wojny hybrydowej przeciwko Ukrainie i krajom Unii Europejskiej. W artykule przedstawiono założenie, że jedynie zmiana retoryki politycznej, a mianowicie uniknięcie populizmu w odniesieniu do relacji historycznych dwóch sąsiadujących ze sobą narodów, wraz ze wzmocnieniem odpowiedzialności korporacyjnej mediów krajowych w kwestiach polityki historycznej, jest w stanie zneutralizować wpływ radykalnych tendencji politycznych zarówno w obu krajach jak i na zewnątrz - zwłaszcza wpływ innych państw, które nie są zainteresowane uporaniem się przez Polskę i Ukrainę z tragicznymi wydarzeniami w historii obu krajów. Celem autorów artykułu nie jest badanie ani porównywanie stanowisk o charakterze czysto historycznym. Chodzi o narzędzia medialne i ich rolę w dyskursie polityki historycznej.

Słowa kluczowe: polityka historyczna, sfera medialna, postprawda, mitologizacja, chaotyzacja przestrzeni informacyjnej, bezpieczeństwo narodowe, wojna hybrydowa, populizm 